\title{
Demography of adults of the Marsh fritillary butterfly, Euphydryas aurinia (Lepidoptera: Nymphalidae) in the Czech Republic: Patterns across sites and seasons
}

\author{
KAmil ZIMMERMANN ${ }^{1,2}$, Pavla BLAZKOVA ${ }^{1}$, Oldrich CIZEK ${ }^{1,3}, Z_{\text {DENEK FRIC }}^{1,2}$, Vladimir HULA ${ }^{4}$, \\ PAVEl KEPKA $^{1,2}$, DAVID NOVOTNY ${ }^{1,2}$, Irena SLAMOVA ${ }^{1,2}$ and MARTin KONVICKA ${ }^{1,2 *}$ \\ ${ }^{1}$ Faculty of Science, University South Bohemia, Branisovska 31, 37005 Ceske Budejovice, Czech Republic; \\ e-mail: konva333@gmail.com \\ ${ }^{2}$ Institute of Entomology, Biological Centre of the Czech Academy of Sciences, Branisovska 31, 37005 Ceske Budejovice, \\ Czech Republic \\ ${ }^{3}$ Hutur o.p.s., J. Purkyne 1616, 50002 Hradec Kralove, Czech Republic \\ ${ }^{4}$ Faculty of Agriculture, Mendel Agricultural University, Zemedelska 1/1665, 61300 Brno, Czech Republic
}

Key words. Lepidoptera, Nymphalidae, Euphydryas aurinia, Marsh fritillary, butterfly conservation, demography, density dependence, grasslands, local dynamics, metapopulation

\begin{abstract}
The Marsh fritillary (Euphydryas aurinia) (Lepidoptera: Nymphalidae) has declined across Europe, including the Czech Republic. Current conservation strategies rely on prevention of habitat loss and degradation, and increase in habitat quality and connectivity via promoting traditional grassland management. The population structure and adult demography parameters of a single population was investigated for eight years (single system), and of all the known Czech populations (multiple populations) for a single year, using mark-recapture. There was substantial variation in the patterns of adult demography, both among years in the single system and among the multiple populations in a single year. In the single system, the date of the first flight of an adult varied by 18 days over the 8 years and total annual numbers varied with a coefficient of variation of 0.40 (females fluctuating more than males). The average density was ca 80 adults/ha. The population size displayed density-dependence, i.e. decreased following years with high adult numbers, with an equilibrium density of 90 individuals/ha. The average density of the multiple populations was ca 120 individuals/ha. The estimated total population for the Czech Republic was 25,000 individuals (17,000 males / 8,000 females) in 2007, which does not indicate an imminent threat of extinction. The regional persistence of E. aurinia is likely to depend on recolonisation of temporarily vacant sites by dispersing individuals, facilitated by local shifts in adult flight phenology to that better adapted to local conditions.
\end{abstract}

\section{INTRODUCTION}

During the last decades, the twin effects of agricultural intensification and abandonment of less productive land caused a loss of semi-natural grassland across Europe, including humid grassland in sub-mountain regions (Sawchik et al., 2003; Sang et al., 2010). Land drainage, fertilisation, merging of originally separate fields, sowing grass mixtures and homogenisation of grazing pressure on the one hand, and scrub encroachment and afforestation schemes on the other hand, have reduced the area of habitat available for many specialised grassland insects (e.g., Oxbrough et al., 2006; Reidsma et al., 2006). Many once-common grassland butterflies have declined in abundance across Europe (Kuussaari et al., 2007; Nilsson et al., 2008; Van Dyck et al., 2009).

Euphydryas aurinia (Rottenburg, 1775) (Lepidoptera: Nymphalidae) is a butterfly threatened by these developments all across Western (e.g., Schtickzelle et al., 2005; Fowles \& Smith, 2006; Bulman et al., 2007), Northern (Saarinen et al., 2005) and Central (Anthes et al., 2003; Hula et al., 2004) Europe. Owing to the extinction of populations in temperate Europe, it has been included onto the EU Habitats and Species Directive (Council Directive 92/43/EEC). Despite a geographic range reaching from Britain to the Amur region and Japan (Tolman \& Lewington, 1997), within which it inhabits diverse biotopes and its larvae develop on many different host plants (Singer et al., 2002; Liu et al., 2006; Stefanescu et al., 2006), populations appear to be regionally host- and habitat-specialised (Warren, 1994; Munguira et al., 1997; Betzholtz et al., 2007; Junker \& Schmitt, 2009). Those inhabiting $\mathrm{W}$ and $\mathrm{C}$ Europe occur in humid to dry nutrient-poor grassland (Konvicka et al., 2003; Bulman et al., 2007), a severely declining habitat.

This is also the case in the Czech Republic, where a decade ago, E. aurinia was known from less than ten sites. Surveys carried out from 2002 onwards led to the discovery of over 100 colonies, all in Western Bohemia (Fig. 1). Most of the colonies are small (mean area: 1.5 ha), the total area of distribution is less than 300 ha, and the colonies display metapopulation dynamics with patch extinctions and colonisation (Hula et al., 2004; Konvicka \& Benes, 2008).

\footnotetext{
* Corresponding author.
} 


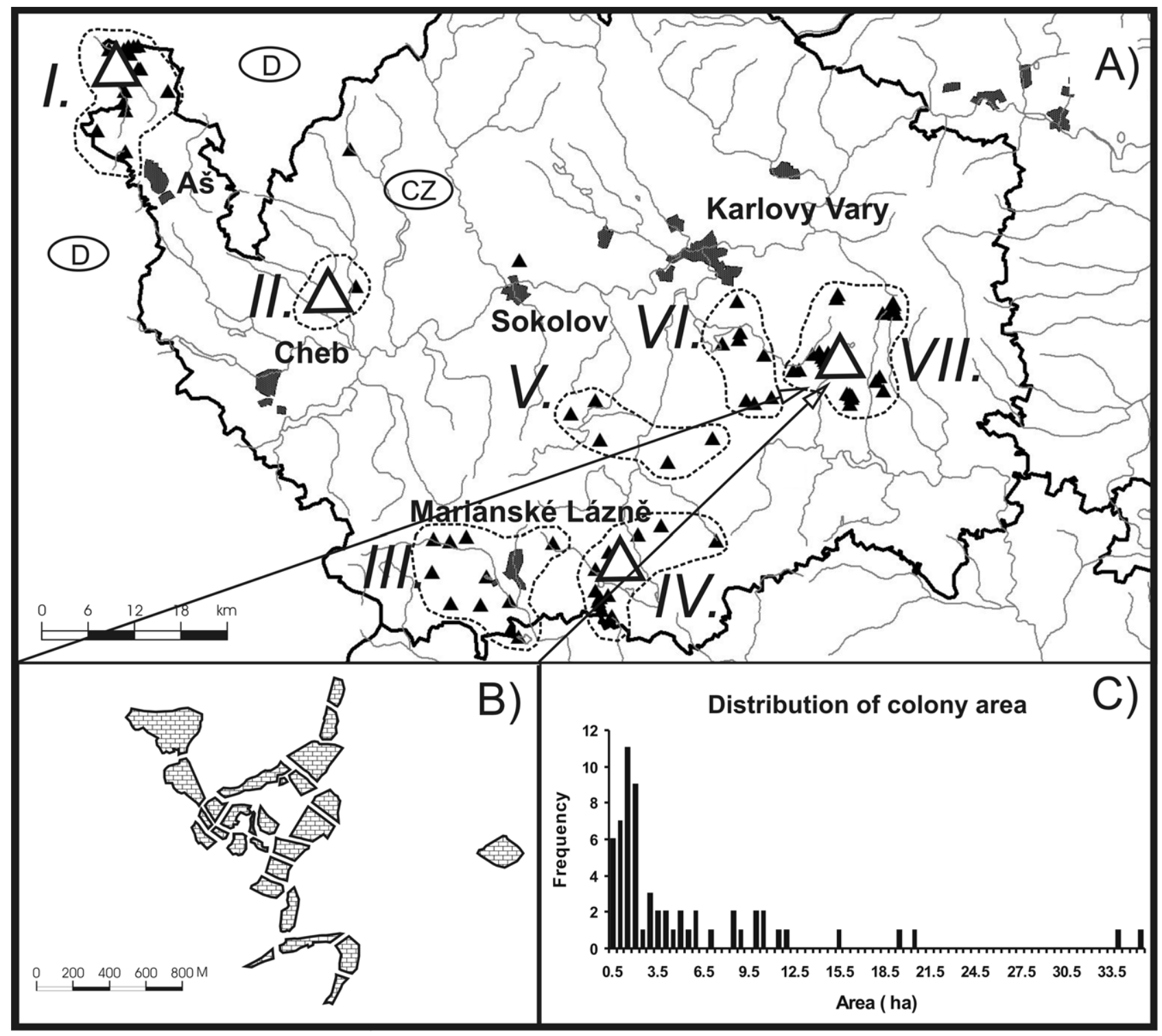

Fig. 1. A - map of all known E. aurinia colonies in W. Bohemia, Czech Republic, 2008, showing major cities, positions of the colonies and (Roman numerals) the clusters used for the multiple populations study; B - detailed chart of the meadows followed in the single system study; $\mathrm{C}$ - histogram showing the sizes of colony areas. Legend: $\boldsymbol{\Delta}$ - present known colonies; $\Delta-$ present strong colonies (hosting > larval nests in 2007); ------ dashed lines - clusters of colonies used in multiple populations study.

The patterns in adult within-patch demography in Czech populations were studied using mark-recapture. This approach is widely used in butterfly ecology, but despite its venerable tradition (e.g., Ehrlich et al., 1975; Ehrlich \& Hanski, 2004) few studies have been done over many seasons using flexible modern approaches (e.g., Fleishman et al., 2002; Schtickzelle et al., 2006), and none on E. aurinia has included many seasons/sites. In other species, such comparisons demonstrate that colonies within metapopulations display considerable variation in internal dynamics (Boggs, 1987; Schtickzelle et al., 2002), as predicted by metapopulation theory (Hanski, 1999); and that short-term data underestimate the magnitude of population changes (Thomas et al., 2002; Hellmann et al., 2003). Recently, density-dependent regulation of population sizes was recorded in mark-recapture studies spanning many seasons (Schtickzelle \& Baguette,
2004; Nowicki et al., 2009), rekindling the debate on the relative importance of density dependence in the population dynamics of specialist insect herbivores.

The setting of this study allows the comparison of variation in basic demography patterns across seven seasons (2002-2008) at a single site, with patterns in a single year (2007) for practically all of the known Czech E. aurinia colonies. Specifically, the intention was to answer the following questions: (i) how do phenological patterns, such as the onset and termination of the adult flight period, vary among years within a single system, and among systems within the region; (ii) how do basic demography parameters calculable from mark-recapture data, such as survival rate, longevity and catchability, vary among years within a single system; (iii) to what extent are survival, longevity and catchability patterns recorded for a single population transferable across sys- 
TABLE 1. Summary of mark-recapture data for Euphydryas aurinia in Western Bohemia, Czech Republic.

\begin{tabular}{|c|c|c|c|c|c|}
\hline & \multirow{2}{*}{ Dates } & \multirow{2}{*}{ Marking days } & Marked & Recaptured & Number of times handled \\
\hline & & & o/ & $\delta / 9$ & $\delta / 9$ \\
\hline \multicolumn{6}{|l|}{ Single system } \\
\hline 2002 & 24.v.-28.vi. & 28 & $654 / 207$ & $289 / 63$ & $1189 / 318$ \\
\hline 2003 & 28.v.-17.vi. & 21 & $705 / 358$ & $412 / 166$ & $1663 / 678$ \\
\hline 2004 & 27.v. $-15 . v i i$. & 39 & $1051 / 142$ & 614 / 63 & $2308 / 214$ \\
\hline 2005 & 27.v.-26.vi. & 30 & $624 / 160$ & $413 / 57$ & $1732 / 261$ \\
\hline 2006 & 6.vi.-6.vii. & 25 & $461 / 167$ & $304 / 74$ & $1103 / 277$ \\
\hline 2007 & 18.v.-16.vi. & 30 & $900 / 291$ & $500 / 98$ & $1827 / 429$ \\
\hline 2008 & 25.v.-26.vi. & 30 & $1249 / 431$ & $679 / 144$ & $2571 / 673$ \\
\hline Total & & & $5644 / 1756$ & $3211 / 665$ & $12393 / 2850$ \\
\hline \multicolumn{6}{|c|}{ Multiple populations } \\
\hline I (580 m a.s.1.) & 18.v.-12.vi. & 22 & $1159 / 410$ & $410 / 158$ & $1835 / 686$ \\
\hline II (440 m a.s.l.) & 18.v.-10.vi. & 21 & 749 / 421 & $296 / 193$ & $1335 / 761$ \\
\hline III (590 m a.s.1.) & 18.v.-15.vi. & 27 & $330 / 129$ & 184 / 65 & 724 / 231 \\
\hline IV (701 m a.s.1.) & 18.v.-14.vi. & 21 & $1546 / 480$ & $341 / 69$ & $2004 / 559$ \\
\hline V (740 m a.s.1.) & 25.v.-16.vi. & 15 & $512 / 312$ & $167 / 89$ & $790 / 433$ \\
\hline VI (620 m a.s.1.) & 21.v.-8.vi. & 17 & $430 / 136$ & $108 / 15$ & $568 / 151$ \\
\hline VII ( $680 \mathrm{~m}$ a.s.l.) & 18.v.-16.vi. & 30 & $2022 / 842$ & $731 / 269$ & 3273 / 1236 \\
\hline Superpopulation & 18.v.-16.v. & 31 & $6748 / 2730$ & $2053 / 858$ & $10529 / 4057$ \\
\hline
\end{tabular}

Single system is located near Bochov, the multiple systems near As(I), Frantiskovy Lazne (II), Marianske Lazne (III), Tepla (IV), Prameny (V), Karlovy Vary (VI) and Bochov (VII).

tems; (iv) is there evidence for density dependent population regulation in the seven-season study, and if so, what is the threshold density, or population carrying capacity?; and finally, (v) what is the size of the population of $E$. aurinia in the Czech Republic and what does this tell us about its present conservation status?

\section{MATERIAL AND METHODS}

\section{Study system}

The adults of Euphydryas aurinia emerge and fly from mid-May until late June in C. Europe. The males acquire females by alternately perching and patrolling and mated females lay eggs in batches on particular host plants. Larvae feed gregariously until autumn, hibernate in communal nests and resume feeding solitarily in early spring. All Czech populations use a single larval host plant, Succisa pratensis (Moench, 1794), which grows in nutrient-poor grassland and fens (Bühler \& Schmid, 2001). Ovipositing females prefer prominent plants growing in rather short sward, e.g., on drier areas within meadows (Konvicka et al., 2003).

\section{Eight year single system study}

The eight year single system study was carried out near Karlovy Vary, W. Czech Republic $\left(50^{\circ} 9^{\prime} \mathrm{N}, 13^{\circ} 2^{\prime} \mathrm{E}\right.$, altitude 650 $\mathrm{m})$, on a hilly piedmont of the volcanic Doupovske Mts. The study area consisted of a network of 30 humid meadows (summed area: $28 \mathrm{ha}$ ), separated from one another by ponds, shrubby hedges and woodland (Fig. 1B). Previously, the demography of Argynnini fritillaries (Zimmermann et al., 2005, 2009) and the dispersal of four butterfly species (Fric et al., 2010), were studied in this area.

Adult butterflies were marked daily from late May to late June from 2002 to 2008. Each day, weather permitting, observers walked a zigzag transect across each of the meadows, with time spent in each meadow proportional to meadow size. Each butterfly captured was marked with a unique number and its sex and position of capture noted before release at the site of capture.

\section{Single year multiple population study}

For the multiple population study, the 82 colonies known to be occupied in 2006 were divided into seven clusters (Fig. 1A), based on their geographic proximity and similarity of conditions. A temporary field base, consisting of one researcher and 2-3 students, was established close to each of the clusters, and we attempted to sample equally each cluster during the flight period (Table 1).

\section{Demography analyses}

Constrained linear models (CLM), applying the methodology of generalised linear models to mark-recapture data, were used (Lebreton et al., 1992; application for butterflies: Schtickzelle et al., 2002). In MARK package (White \& Burnham, 1999), the Jolly-Seber method, POPAN parameterisation, suitable for open populations with births, deaths, emigration and immigration was used. This method estimates three primary parameters, daily residence rate, $\phi_{i}$ (combining mortality and emigration in open populations), catchability $p_{i}$, and the proportional probability of entering the population, Pent. Derived parameters are daily births, $B_{i}$, daily population size, $N_{i}$, and total population size, $N_{\text {tot. }}$.

The primary parameters can be independent of sex and the day on which each butterfly was marked - i.e., (.) in MARK notations -, can differ between sexes $(g)$, or can respond to time in a factorial $(t)$, linear $(T)$ or a polynomial $\left(T^{2}, T^{3}\right)$ manner. Sextime interactions can be either additive - e.g., $(g+t)$, or multiplicative - e.g., $\left(g^{*} T^{2}\right)$. From sets of models differing in parametrisation, MARK selects model(s) having high explanatory power with minimum redundant parameters, using the information theory approach (quasi-Akaike information criterion, $c A I C$ ), herein referred as Best models.

To obtain single ("average") values of residence $\left(\phi^{\prime}\right)$ and catchability $\left(p^{\prime}\right)$ for each year or system, the most appropriate POPAN model in which these two parameters were fixed not to depend on time were computed. These models, herein referred to as Common residence and Common catchability models, were used to compare residence and catchability among sexes, seasons and populations. Average residence $\phi^{\prime}$ was converted into 
residence time (or "longevity") using the formula $-\left(\ln \phi^{\prime}\right)^{-1}$ (Cook et al., 1967).

\section{Density dependence and carrying capacity}

Density is estimated population size divided by area. Plotting annual population changes $N_{\text {tot(y) }} / N_{\text {tot( }(y+1)}$, against population densities, $N_{\text {tot(y) }}$, (Akgakaya et al., 1999) and solving the resulting exponential equation via nonlinear estimation, indicates whether density dependent changes occurred in adult numbers in the single population. The population density where $N_{\text {tot }(y+1) /} N_{t o t(y)}=$ 1 is the carrying capacity, $K$.

\section{RESULTS}

\section{Single system}

During the seven seasons, 7,400 individuals were marked of which 3,876 were recaptured (Table 1). Mean annual captures were $806(\mathrm{SD}=274.0)$ males and 251 $(\mathrm{SD}=111.5)$ females. Female captures varied more among years than male captures, with respective coefficients of variation (CV) of 0.44 for females and 0.34 for males. Phenologically, the difference between the earliest (mid-May, 2007) and latest (first week of June, 2006) flights was 18 days. The records of the last individuals spanned from late June (e.g., 2007) to mid-July (2006). The annual flight periods lasted between three to four weeks.

All Best models (Table 2, Fig. 2) indicate that the probability of capture $p$ differed between sexes and varied factorially with the day on which they were marked. The pattern was additive in all years, with $p$ always higher for males. Residence rates $\phi$ remained constant but differed between sexes in five years, but an additive interaction was recorded in 2002 and 2007. The proportional recruit- ment Pent always displayed time-sex interactions, additive in five and multiplicative in two years, and followed domed patterns in six years. Protandry, or earlier recruitment of males, was apparent in all years (Fig. 2).

The fit of the Common residence and Common catchability models was reasonably good, and could be used to provide standard errors of estimated parameters, except in the case of the poorly fitting Common catchability model for 2002 (Tables 3, 4). The Common residence models (Table 3) indicate that the males stayed in the areas in which they were initially caught for longer than the females in four years $(2002,2003,2005,2008)$ and for a shorter period in three years $(2004,2006,2007)$. The resulting average residences $\phi^{\prime}$ did not differ between sexes (males: $0.898 \pm 0.0249 \mathrm{SD}$, females $0.893 \pm 0.0310$ $\mathrm{SD}$; paired $\left.t_{6}=0.43, P=0.68\right)$. The derived average longevity was 10.1 days (range: 7.3-18.0) for males and 9.6 days (6.4-16.4) for females. The Common catchability models (Table 4) indicate that the average annual catchabilities $p^{\prime}$ were higher for males $(0.164 \pm 0.0318 \mathrm{SD})$ than for females $(0.085 \pm 0.0485 \mathrm{SD})$ (paired $t_{6}=3.78, P$ $<0.01)$.

The annual values for longevity and catchability, computed separately for males and females, did not correlate with the days on which the butterflies were marked in each year (all $P>0.1$ ). This observation shows that the patterns did not depend on the duration of the study in individual years.

Estimates of total populations $N_{\text {tot }}$ summed for both sexes never dropped below 1000 individuals (Table 2, Fig. 2). The values varied with a $\mathrm{CV}=0.40$. Females fluctuated more $(\mathrm{CV}=0.50)$ than males $(\mathrm{CV}=0.43)$. The

TABLE 2. The Best Jolly-Seber mark-recapture models and derived estimates of population sizes, sex ratios and population densities of the Euphydryas aurinia butterfly in the Czech Republic.

\begin{tabular}{|c|c|c|c|c|c|c|c|c|c|c|}
\hline & Models & $c A I C$ & No. par. & $N_{\text {tot }} \pm \mathrm{SE}$ & $N_{\text {tot } q} \pm \mathrm{SE}$ & $R$ & $N_{t o t}$ & $D_{\text {ठे }}$ & $D_{q}$ & $D_{\text {ठㅇ }}$ \\
\hline \multicolumn{11}{|c|}{ Single system } \\
\hline 2002 & $\phi(g+t) p(g+t) \operatorname{Pent}(g+T) N(g)$ & 3893.2 & 58 & $2440 \pm 4306$ & $550 \pm 98$ & 4.44 & 2990 & 87 & 20 & 107 \\
\hline 2003 & $\phi(g) p(g+t) \operatorname{Pent}\left(g+T^{2}\right) N(g)$ & 6241.8 & 30 & $1410 \pm 73$ & $710 \pm 43$ & 1.99 & 2120 & 50 & 25 & 76 \\
\hline 2004 & $\phi(g) p(g+t) \operatorname{Pent}\left(g+T^{2}\right) N(g)$ & 7386.4 & 46 & $3050 \pm 248$ & $280 \pm 22$ & 10.89 & 3330 & 109 & 10 & 119 \\
\hline 2005 & $\phi(g) p(g+t) \operatorname{Pent}\left(g+T^{2}\right) N(g)$ & 6587.3 & 39 & $905 \pm 29$ & $360 \pm 34$ & 2.51 & 1265 & 32 & 13 & 45 \\
\hline 2006 & $\phi(g) p(g+t) \operatorname{Pent}\left(g^{*} T^{2}\right) N(g)$ & 4174.8 & 36 & $700 \pm 38$ & $325 \pm 38$ & 2.16 & 1025 & 25 & 12 & 37 \\
\hline 2007 & $\phi\left(g+T^{2}\right) p(g+t) \operatorname{Pent}\left(g+T^{2}\right) N(g)$ & 7028.9 & 35 & $1600 \pm 81$ & $695 \pm 56$ & 2.30 & 2295 & 57 & 25 & 82 \\
\hline 2008 & $\phi(g) p(g+t) \operatorname{Pent}\left(g^{*} T^{2}\right) N(g)$ & 9777.1 & 40 & $2110 \pm 52$ & $1090 \pm 69$ & 1.93 & 3200 & 75 & 39 & 114 \\
\hline \multicolumn{11}{|c|}{$\begin{array}{l}\text { Multiple } \\
\text { populations }\end{array}$} \\
\hline I & $\phi(g+t) p(g+t) \operatorname{Pent}\left(g+T^{2}\right) N(g)$ & 6695.2 & 52 & $3000 \pm 272$ & $1000 \pm 75$ & 3.00 & 4000 & 71 & 24 & 95 \\
\hline II & $\phi(g) p(g+t) \operatorname{Pent}\left(g+T^{2}\right) N(g)$ & 4783.6 & 30 & $2275 \pm 178$ & $1140 \pm 89$ & 2.00 & 3415 & 126 & 63 & 190 \\
\hline III & $\phi(g) p(g+t) \operatorname{Pent}(g+T) N(g)$ & 3100.1 & 35 & $610 \pm 35$ & $240 \pm 21$ & 2.54 & 850 & 14 & 6 & 20 \\
\hline IV & $\phi(g) p(g+t) \operatorname{Pent}(g+T) N(g)$ & 4767.3 & 29 & $6835 \pm 438$ & $2650 \pm 305$ & 2.58 & 9485 & 273 & 106 & 379 \\
\hline V & $\phi(g+t) p(t) \operatorname{Pent}\left(g+T^{2}\right) N(g)$ & 2231.0 & 36 & $3580 \pm 967$ & $980 \pm 114$ & 3.65 & 4560 & 82 & 23 & 105 \\
\hline VI & $\phi\left(g^{*} t\right) p\left(g^{*} t\right) \operatorname{Pent}\left(g^{*} T^{2}\right) N(g)$ & 1202.0 & 27 & $1325 \pm 2252$ & $1420 \pm 45297$ & 0.93 & 2745 & 22 & 24 & 46 \\
\hline VII & $\phi(g+t) p(g * t) \operatorname{Pent}\left(g^{*} T^{2}\right) N(g)$ & 11772.2 & 89 & $4280 \pm 127$ & $2360 \pm 133$ & 1.81 & 6640 & 46 & 25 & 71 \\
\hline
\end{tabular}

\begin{tabular}{llll}
\hline $\begin{array}{l}\Sigma \text { multiple } \\
\text { populations }\end{array}$ & 21905 & 9760 & 31695
\end{tabular}

\begin{tabular}{lllllllllll}
\hline Superpopulation & $\phi(g+t) p\left(g^{*} t\right) \operatorname{Pent}\left(g^{*} T^{2}\right) N(g)$ & 35972.2 & 104 & $16895 \pm 0$ & $8460 \pm 0$ & 2.00 & 25350 & 52 & 26 & 78
\end{tabular}

Models - selected Best model, cAIC - quasi-Akaike information criterion, No. par. - number of parameters, $N_{\text {tot }{ }^{*}} \pm \mathrm{SE}$ - estimated population size of $\hat{\delta}, N_{t o t} \pm \mathrm{SE}$ - estimated population size of $q, R$ - estimated sex ratio V: $\uparrow, N_{t o t}$ - estimated total population size, $D_{\delta}-$ number of males $/$ ha, $D_{\text {}}-$ number of females $/$ ha, $-D_{\text {ठ }}-$ total de/ha. 

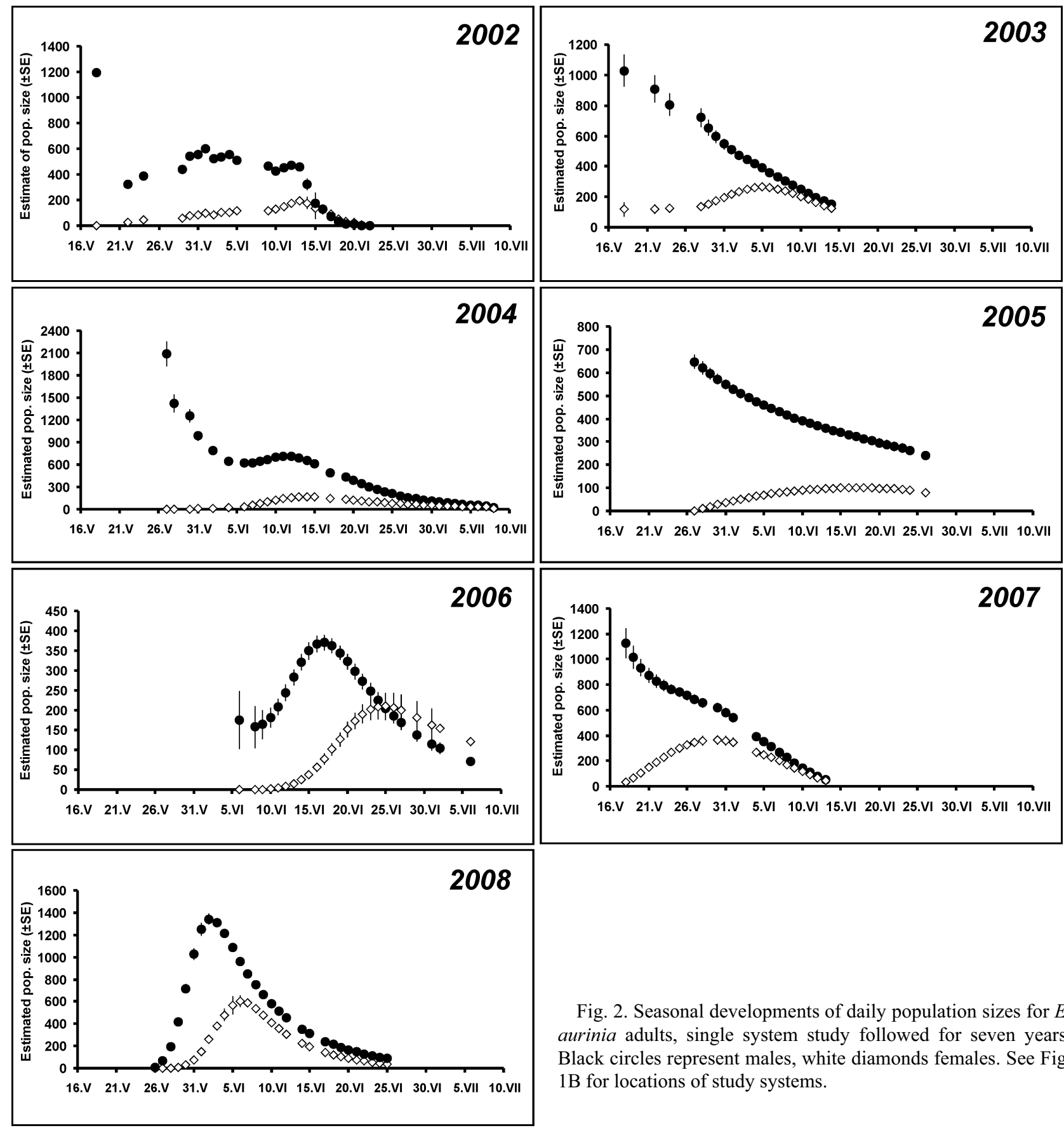

Fig. 2. Seasonal developments of daily population sizes for $E$. aurinia adults, single system study followed for seven years. Black circles represent males, white diamonds females. See Fig. 1B for locations of study systems.

estimated sex ratios were male biased in all years. The lowest annual numbers of females were close to 300 individuals $(2004,2005,2006)$. The estimates of total annual numbers of males and females did not correlate with average catchability of sexes (all $P>0.1$ ).

\section{Multiple populations}

A total of 9,478 individuals were marked of which 2,911 were recaptured, including the individuals recorded in the single system study in 2007 (Table 1). The timing of flight periods differed among the systems. At low altitudes (systems I, II, III), males had already started flying when the marking began, whereas at high altitudes (VI, VII), males started to appear at the time the marking

began. There was a corresponding shift in the time of when the last individuals were marked (Fig. 3).

Best models (Table 2) indicate a more complex pattern for the Multiple populations than the single system. Residence was independent of time but differed between sexes in three systems (II-IV), and responded to (factorial) time in the rest, in three cases additively and in one (VI) multiplicatively. The pattern in catchability was also more complex. A more factorial response to time $(t)$ was indicated for one system (V), additive responses $(g+t)$ for four systems and multiplicative $\left(g^{*} t\right)$ response for two systems (VI, VII). There was consistently a time-sex interaction in the recruitment, Pent, five times additive and two times multiplicative; the response was 

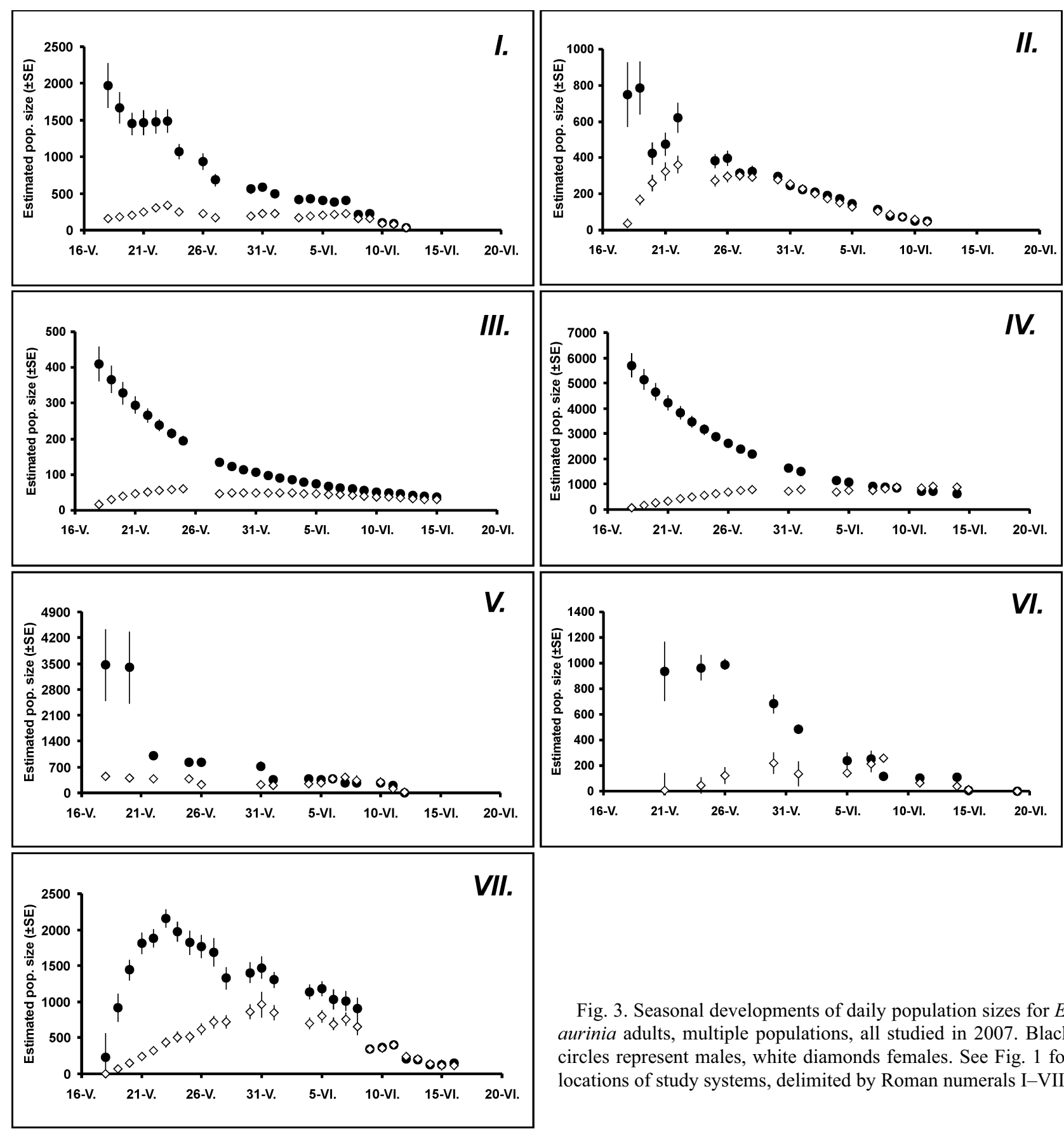

Fig. 3. Seasonal developments of daily population sizes for $E$. aurinia adults, multiple populations, all studied in 2007. Black circles represent males, white diamonds females. See Fig. 1 for locations of study systems, delimited by Roman numerals I-VII.

linear in two systems (III + IV) and polynomial in the rest; and protandry was apparent in all systems (Fig. 4).

The fit of the Common residence and Common catchability models was reasonably good and indicated low standard errors for the estimated parameters (Table 3, 4). Common residence models (Table 3 ) revealed no differences in average residence $\phi^{\prime}$ between sexes (males: $0.861 \pm 0.0439$, females: $0.849 \pm 0.0378$, paired $t_{6}=0.97$, $P=0.37)$. Male residence was positively correlated with altitude $\left(r_{\mathrm{s}}=0.79, t_{7}=2.84, P<0.03\right)$ but no correlation in the case of females $\left(r_{\mathrm{s}}=0.46, t_{7}=1.17, P=0.29\right)$. The average longevity was 7.1 days for males (range: $3.8-9.0$ ) and 6.5 days for females (range: 4.3-10.2).

The Common catchability models (Table 4) indicated that females were less catchable in two systems (I, VII).

The average male catchability $p^{\prime}$ was significantly higher $(0.158 \pm 0.0687 \mathrm{SD})$ than that of females $(0.111 \pm 0.0439$ SD) (paired $t_{6}=2.51, P=0.046$ ). As in the single-system study, neither average residence nor average catchability, are correlated with the total number of days over which the butterflies were marked (all $P>0.1$ ).

Estimates of $N_{\text {tot }}$ showed that all studied systems except III hosted thousands of adults; the largest one being IV (over 9000 individuals), followed by VII and V. The sex ratio was male biased in all systems but VI. Recalculating the population sizes in terms of density gave ranges of 14-273 (males), 6-106 (females) and 20-379 (both sexes) / ha. 

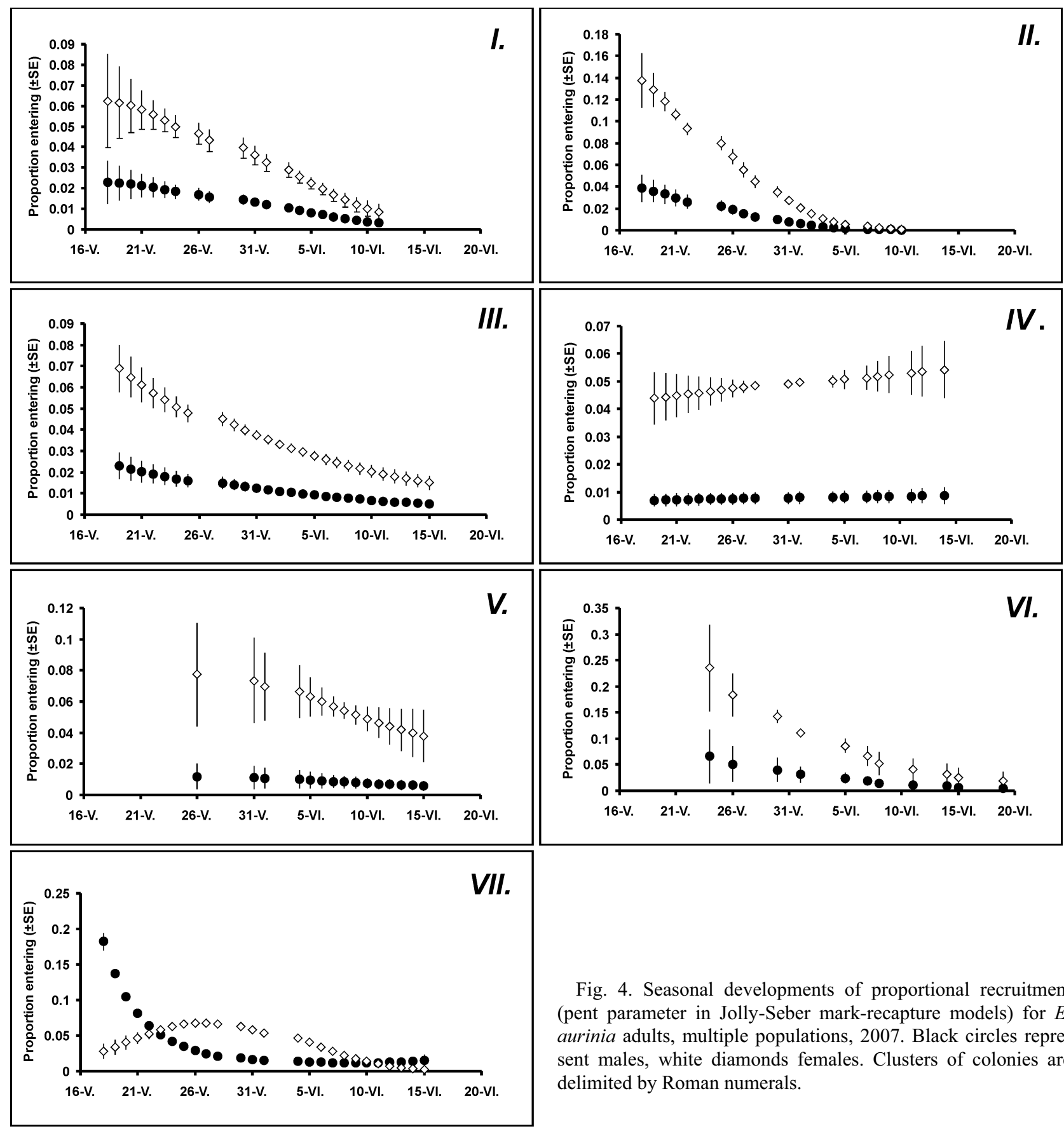

Fig. 4. Seasonal developments of proportional recruitment (pent parameter in Jolly-Seber mark-recapture models) for $E$. aurinia adults, multiple populations, 2007. Black circles represent males, white diamonds females. Clusters of colonies are delimited by Roman numerals.

\section{Single system vs. multiple populations}

Comparing the average residences $\phi^{\prime}$ from the single system (males $0.898 \pm 0.0249$ SD, females: $0.893 \pm$ 0.0310 ) with those recorded for the multiple populations showed that average single system residence was marginally higher than multiple populations residences for males (single-sample $t, t_{6}=-2.26, P=0.06$ ) and significantly higher for females $\left(t_{6}=-3.05, P<0.05\right)$. Average single system catchabilities (males: $0.164 \pm 0.0318$, females: $0.085 \pm 0.0485)$ did not differ from those recorded for multiple populations (males: $t_{6}=-0.22, P=0.83$; females: $\left.t_{6}=1.54, P=0.17\right)$.

Average residence correlated negatively with density in the single system, females $\left(r_{s}=-0.810, t_{7}=-3.10, P<\right.$ 0.05 ), implying that high density either diminished sur-

vival or increased emigration. This was not recorded for males in the single system $\left(r_{s}=-0.500, t_{7}=-1.29, P=\right.$ $0.25)$, or for both sexes in the multiple populations (males: $r_{s}=0.071, t_{7}=0.16, P=0.88$; females: $r_{s}=0.252$, $\left.t_{7}=0.58, P=0.59\right)$. Average catchability was not influenced by density, neither in the single system (males: $r_{s}=$ $-0.234, t_{7}=-0.54, P=0.61$; females: $r_{s}=-0.450, t_{7}=$ $-1.28, P=0.31$ ), nor across multiple populations (males: $r_{s}=-0.500, t_{7}=-1.29, P=0.25$; females: $r_{s}=-0.234, t_{7}=$ $-0.54, P=0.61)$.

\section{Density dependence and total population in the Czech Republic}

The average annual population density/ha in the single system (males: $62.1 \pm 30.11$, females: $20.6 \pm 10.18$, both 
TABLE 3. The Common residence population size models for the Czech Republic populations of Euphydryas aurinia butterfly. The models used to compare residence and longevity values across years and sites were selected from sets of alternative models that had the lowest- $c A I C$ values and in which residence did not depend on time but differed between sexes (MARK notation: $\phi(g)$ ).

\begin{tabular}{|c|c|c|c|c|c|c|c|c|c|c|c|c|}
\hline & Models & $c A I C$ & $\begin{array}{l}\text { No. } \\
\text { par. }\end{array}$ & $\phi_{\text {ठ }} \pm \mathrm{SE}$ & $\phi_{9} \pm \mathrm{SE}$ & $L_{\text {ठे }}$ & $L_{q} 1$ & $L_{\max \delta}$ & $L_{\max q}$ & $N_{\text {totơ }} \pm \mathrm{SE}$ & $N_{t o t 9} \pm \mathrm{SE}$ & $N_{\text {tot. }}$ \\
\hline \multicolumn{13}{|c|}{$\begin{array}{l}\text { Single } \\
\text { system }\end{array}$} \\
\hline 2002 & $\phi(g) p(g+t) \operatorname{Pent}(g+T) N(g)$ & 3937.1 & 34 & $0.904 \pm 0.00850$ & $0.879 \pm 0.0213$ & 9.9 & 7.8 & 20 & 21 & $2145 \pm 171$ & $575 \pm 70$ & 2720 \\
\hline 2003 & $\phi(g) p(g+t) \operatorname{Pent}\left(g+T^{2}\right) N(g)$ & 6241.8 & 30 & $0.872 \pm 0.00720$ & $0.862 \pm 0.0132$ & 7.3 & 6.7 & 18 & 15 & $1410 \pm 73$ & $710 \pm 43$ & 2120 \\
\hline 2004 & $\phi(g) p(g+t) \operatorname{Pent}\left(g+T^{2}\right) N(g)$ & 7386.4 & 46 & $0.879 \pm 0.00570$ & $0.916 \pm 0.0153$ & 7.8 & 11.4 & 28 & 21 & $3050 \pm 248$ & $280 \pm 22$ & 3330 \\
\hline 2005 & $\phi(g) p(g+t) \operatorname{Pent}\left(g+T^{2}\right) N(g)$ & 6587.3 & 39 & $0.946 \pm 0.00370$ & $0.883 \pm 0.0179$ & 18.0 & 8.0 & 28 & 17 & $905 \pm 29$ & $360 \pm 34$ & 1265 \\
\hline 2006 & $\phi(g) p(g+t) \operatorname{Pent}\left(g * T^{2}\right) N(g)$ & 4174.8 & 36 & $0.907 \pm 0.00910$ & $0.941 \pm 0.0223$ & 10.2 & 16.4 & 18 & 12 & $700 \pm 38$ & $325 \pm 38$ & 1025 \\
\hline 2007 & $\phi(g) p(g+t) \operatorname{Pent}\left(g+T^{2}\right) N(g)$ & 7031.1 & 33 & $0.899 \pm 0.00580$ & $0.911 \pm 0.0146$ & 9.4 & 10.7 & 26 & 21 & $1570 \pm 55$ & $680 \pm 55$ & 2250 \\
\hline 2008 & $\phi(g) p(g+t) \operatorname{Pent}\left(g * T^{2}\right) N(g)$ & 9777.1 & 40 & $0.882 \pm 0.00480$ & $0.856 \pm 0.0099$ & 8.0 & 6.4 & 23 & 20 & $2110 \pm 52$ & $1090 \pm 69$ & 3200 \\
\hline \multicolumn{13}{|c|}{$\begin{array}{l}\text { Multiple } \\
\text { populations }\end{array}$} \\
\hline I & $\phi(g) p(g+t) \operatorname{Pent}\left(g+T^{2}\right) N(g)$ & 6700.0 & 31 & $0.860 \pm 0.00630$ & $0.874 \pm 0.0106$ & 6.6 & 7.4 & 21 & 21 & $3090 \pm 152$ & $935 \pm 56$ & 4025 \\
\hline II & $\phi(g) p(g+t) \operatorname{Pent}\left(g+T^{2}\right) N(g)$ & 4783.6 & 30 & $0.766 \pm 0.01060$ & $0.792 \pm 0.0149$ & 3.8 & 4.3 & 21 & 14 & $2275 \pm 178$ & $1140 \pm 89$ & 3415 \\
\hline III & $\phi(g) p(g+t) \operatorname{Pent}(g+T) N(g)$ & 3100.1 & 35 & $0.861 \pm 0.00870$ & $0.841 \pm 0.0185$ & 6.7 & 5.8 & 22 & 13 & $610 \pm 35$ & $240 \pm 21$ & 850 \\
\hline IV & $\phi(g) p(g+t) \operatorname{Pent}(g+T) N(g)$ & 4767.3 & 29 & $0.895 \pm 0.00820$ & $0.907 \pm 0.0181$ & 9.0 & 10.2 & 24 & 20 & $6835 \pm 438$ & $2650 \pm 305$ & 9485 \\
\hline $\mathrm{V}$ & $\phi(g) p(t) \operatorname{Pent}\left(g+T^{2}\right) N(g)$ & 2255.8 & 23 & $0.873 \pm 0.01470$ & $0.854 \pm 0.0238$ & 7.4 & 6.3 & 16 & 14 & $2190 \pm 286$ & $1315 \pm 230$ & 3505 \\
\hline VI & $\phi(g) p(g * t) \operatorname{Pent}\left(g * T^{2}\right) N(g)$ & 1237.6 & 34 & $0.877 \pm 0.01490$ & $0.816 \pm 0.0387$ & 7.6 & 4.9 & 21 & 10 & $1560 \pm 376$ & $1270 \pm 459$ & 2830 \\
\hline VII & $\phi(g) p(g * t) \operatorname{Pent}\left(g * T^{2}\right) N(g)$ & 11838.2 & 64 & $0.892 \pm 0.00510$ & $0.862 \pm 0.0103$ & 8.7 & 6.7 & 24 & 21 & $4620 \pm 192$ & $2470 \pm 147$ & 7090 \\
\hline
\end{tabular}

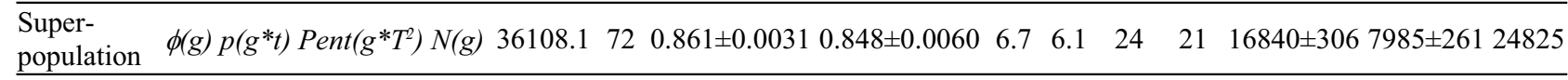

Models - selected Best model, cAIC - quasi-Akaike information criterion, No. par. - number of parameters, $\phi_{\delta} \pm \mathrm{SE}-\mathrm{estimate}$ of

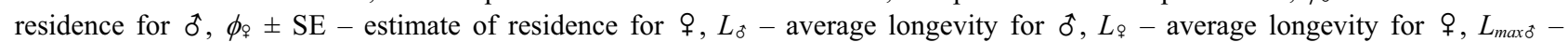
maximum documented observed longevity for $\hat{\delta}, L_{\max } \uparrow$ - maximum documented observed longevity for $\uparrow, N_{\text {toto }} \pm \mathrm{SE}-$ estimated

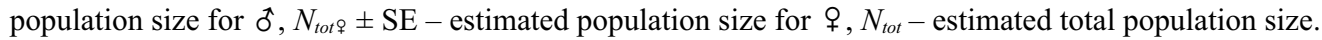

sexes $82.9 \pm 32.77)$ was lower than that recorded in the multiple populations (males: $90.6 \pm 89.02$; females: 38.7 \pm 34.29 ; both sexes $129.4 \pm 122.53$ ), but the differences were not statistically significant (males $t_{6}=0.90, P=$ 0.40 ; females $t_{6}=1.40, P=0.21$; both sexes $t_{6}=1.00, P=$ $0.35)$.

Within the single system, yearly changes in population size exhibited negative density dependence, with carrying capacity $K$ close to 90 individuals per hectare (Fig. 5); thus, the average value recorded for the single system was slightly below the carrying capacity, whereas those in multiple populations exceeded it.

Collated data from multiple systems, 2007, were used to estimate total population size ("Superpopulation") of E. aurinia in the Czech Republic. The computation is based on 9,478 marked and 2,911 recaptured individuals (Table 1). The resulting Superpopulation model contained an additive sex and factorial time interaction, $(g+t)$ for residence, a multiplicative $\left(g^{*} t\right)$ pattern for catchability and proportional recruitment responding multiplicatively to a polynomial of time $\left(g^{*} T^{2}\right)$ (Table 2 .). The estimated total population was 25,350 individuals $(16,900$ males $/$ 8,500 females). Summing the seven separate estimates for multiple populations returned 31,695 individuals $(21,905$ males / 9,760 females), a higher value, whereas the multiplication of total occupied area by carrying capacity $K=$ 90 gives an equilibrium population of 27,000 individuals, which is close to the Superpopulation estimate.

\section{DISCUSSION}

This analysis of extensive data on the adult demography of Euphydryas aurinia revealed substantial variation both among years within the single population and among multiple populations in a single year. The study of

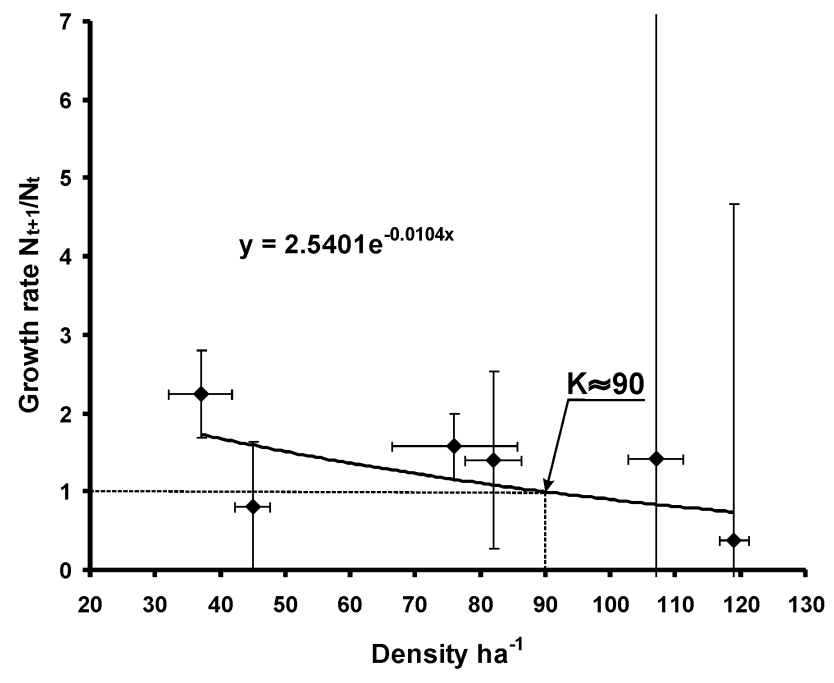

Fig. 5. Detection of density dependence in E. aurinia adults, single system, followed 2002-2008. The changes of total population size between two consecutive years are plotted against annual densities. Intersection of the fitted negative exponential curve $(R 2-0.29)$ with Growth rate $=1$ gives an equilibrium population density per hectare of habitat area ( $\approx 90$ individuals). 
TABLE 4. The Common catchability models for the Czech Republic populations of the Euphydryas aurinia butterfly. The models used to compare catchability across years and sites were selected from sets of alternative models that had the lowest- $c A I C$ values and in which catchability did not depend on time but differed between sexes (MARK notation: $p(g)$ ).

\begin{tabular}{|c|c|c|c|c|c|c|c|c|}
\hline & Models & $c A I C$ & No. par. & $p_{\text {ठ }} \pm \mathrm{SE}$ & $p_{\text {里 }} \pm \mathrm{SE}$ & $N_{\text {toto }} \pm \mathrm{SE}$ & $N_{\text {tot } 9} \pm \mathrm{SE}$ & $N_{\text {tot }}$ \\
\hline \multicolumn{9}{|l|}{$\begin{array}{l}\text { Single } \\
\text { system }\end{array}$} \\
\hline 2002 & $\phi(g+t) \underline{p}(g) \operatorname{Pent}(g+T) N(g)$ & 4034.7 & 34 & $0.145 \pm 0.0086$ & $0.071 \pm 0.0086$ & $3380 \pm 141985$ & $4100 \pm 142113$ & 7480 \\
\hline 2003 & $\phi(g) p(g) \operatorname{Pent}\left(g+T^{2}\right) N(g)$ & 7084.7 & 10 & $0.191 \pm 0.0083$ & $0.01 \pm 0.0088$ & $1200 \pm 39$ & $640 \pm 38$ & 1840 \\
\hline 2004 & $\phi(g) p(g) \operatorname{Pent}\left(g+T^{2}\right) N(g)$ & 8363.6 & 10 & $0.177 \pm 0.0059$ & $0.077 \pm 0.0101$ & $2020 \pm 59$ & $440 \pm 49$ & 2460 \\
\hline 2005 & $\phi(g) p(g) \operatorname{Pent}\left(g+T^{2}\right) N(g)$ & 7556.8 & 10 & $0.124 \pm 0.0046$ & $0.114 \pm 0.0151$ & $900 \pm 26$ & $365 \pm 35$ & 1265 \\
\hline 2006 & $\phi(g) p(g) \operatorname{Pent}\left(g * T^{2}\right) N(g)$ & 4353.8 & 12 & $0.215 \pm 0.0104$ & $0.164 \pm 0.0196$ & $770 \pm 29$ & $355 \pm 31$ & 1125 \\
\hline 2007 & $\phi\left(g+T^{2}\right) p(g) \operatorname{Pent}\left(g+T^{2}\right) N(g)$ & 7279.9 & 12 & $0.148 \pm 0.0062$ & $0.057 \pm 0.0057$ & $1540 \pm 58$ & $690 \pm 57$ & 2230 \\
\hline 2008 & $\phi(g) p(g) \operatorname{Pent}\left(g^{*} T^{2}\right) N(g)$ & 10539.8 & 12 & $0.145 \pm 0.0044$ & $0.104 \pm 0.0095$ & $2455 \pm 65$ & $1165 \pm 73$ & 3618 \\
\hline \multicolumn{9}{|l|}{$\begin{array}{l}\text { Multiple } \\
\text { populations }\end{array}$} \\
\hline I & $\phi(g+t) p(g) \operatorname{Pent}\left(g+T^{2}\right) N(g)$ & 6853.4 & 31 & $0.138 \pm 0.0068$ & $0.153 \pm 0.0106$ & $2625 \pm 110$ & $910 \pm 55$ & 3535 \\
\hline II & $\phi(g) p(g) \operatorname{Pent}\left(g+T^{2}\right) N(g)$ & 5041.0 & 10 & $0.220 \pm 0.0127$ & $0.136 \pm 0.0107$ & $1685 \pm 73$ & $945 \pm 54$ & 2630 \\
\hline III & $\phi(g) p(g) \operatorname{Pent}(g+T) N(g)$ & 3381.8 & 9 & $0.262 \pm 0.0134$ & $0.134 \pm 0.0196$ & $525 \pm 22$ & $240 \pm 21$ & 765 \\
\hline IV & $\phi(g) p(g) \operatorname{Pent}(g+T) N(g)$ & 5852.7 & 9 & $0.055 \pm 0.0033$ & $0.020 \pm 0.0021$ & $5440 \pm 250$ & $1810 \pm 185$ & 7250 \\
\hline $\mathrm{V}$ & $\phi(g+t) p(g) \operatorname{Pent}\left(g+T^{2}\right) N(g)$ & 2543.8 & 24 & $0.159 \pm 0.0158$ & $0.095 \pm 0.0122$ & $1330 \pm 100$ & $990 \pm 102$ & 2320 \\
\hline VI & $\phi\left(g^{*} t\right) p(g) \operatorname{Pent}\left(g^{*} T^{2}\right) N(g)$ & 1336.9 & 34 & $0.167 \pm 0.0194$ & $0.122 \pm 0.0348$ & $1410 \pm 237$ & $815 \pm 208$ & 2225 \\
\hline VII & $\phi(g+t) p(g) \operatorname{Pent}\left(g^{*} T^{2}\right) N(g)$ & 12432.9 & 38 & $0.107 \pm 0.0041$ & $0.114 \pm 0.0069$ & $4345 \pm 143$ & $2300 \pm 11$ & 6645 \\
\hline $\begin{array}{l}\begin{array}{l}\text { Super- } \\
\text { population }\end{array} \\
\end{array}$ & $\phi(g+t) p(g) \operatorname{Pent}\left(g * T^{2}\right) N(g)$ & 39317.1 & 42 & $0.073 \pm 0.0013$ & $0.091 \pm 0.0030$ & $13830 \pm 213$ & $7200 \pm 200$ & 21030 \\
\hline
\end{tabular}

Models - selected Best model, cAIC - quasi-Akaike information criterion, No. par. - number of parameters, $p_{\delta} \pm \mathrm{SE}-\mathrm{estimated}$

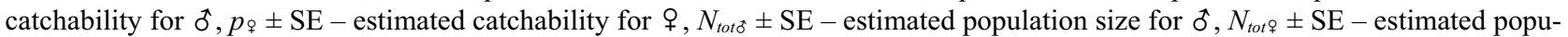

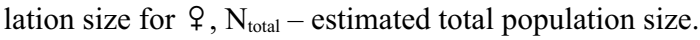

the single system over 8 years revealed density-dependent decreases in numbers following years of high abundance, whereas the comparison of multiple populations provided insights into the regional persistence of this species.

\section{Residence, catchability and recruitment}

The internal structures of the demography models, i.e. sex and time related responses of residence, catchability and recruitment, were more consistent among seasons within the single system than among multiple populations in a single year. As the single system field study was carried out in a more familiar environment in which it was easy to adapt marking to the temporal variability in the availability of nectar, mowing of parts of the grassland during the study period, or within-season shifts in the distribution of individuals, the single system results are considered to be more reliable. In the less familiar conditions of the multiple populations, it is likely that factors such as apparent emigration (butterflies temporarily leaving the sites) affected the results.

Most of the models indicate that males are more likely to be caught; catchability varied with when marked; hump-shaped patterns of recruitment and daily population size; and protandry, manifested in earlier beginnings and peaks of male recruitment. Similar patterns of residence, catchability and recruitment are reported in many MR studies of butterflies with discrete generations (e.g. Boggs, 1987; Nève et al., 1996; Wahlberg et al., 2002; Zimmermann et al., 2009; Fric et al., 2010). For E. aurinia the CLM approach was used to estimate adult num- bers in diminishing populations in Belgium (Schtickzelle et al., 2005), in a highly abundant but fragmented population in Portugal (Junker \& Schmitt, 2009) (both single seasons) and in a population inhabiting extreme conditions above the timberline in the Alps (Junker et al., 2010) (two seasons). Among other butterflies, particularly relevant are studies of the Argynnini nymphalids Proclossiana eunomia (eight seasons: Schtickzelle et al., 2002) and Boloria aquilonaris (three seasons, four systems: Baguette \& Schtickzelle, 2003).

Despite common patterns, there was considerable variation among years in the single system and among multiple populations in a single year. First, single system residence was consistently higher than in multiple populations. The simplest interpretation is that the more familiar working situation in the former, in which the marking of butterflies started early in the flight period, whereas in the latter, the beginning of the male flight period in systems $\mathrm{I}-\mathrm{V}$ was missed and this resulted in lower estimated residences. Only for females in the single system was there a negative correlation between residence and density. This may imply a decrease in female survival or increase in female emigration (Baguette et al., 1998).

E. aurinia residence was constant in time but differed between sexes in nine out of fourteen Best models, but there was no consistent difference between sexes. Similar variation in demographic patterns is revealed by the analysis of Nowicki et al. (2009) of a large data set on lycaenid butterflies. Residence constant in time implies that the probability of surviving for a further day is inde- 
pendent of their age when marked (i.e., mortality factors affect young and old adults similarly). This contrasts with the findings of Baguette \& Schtickzelle (2003) on Boloria aquilonaris and Schtickzelle et al. (2002) on Proclossiana eunomia, which indicate residence often decreases linearly with age, allegedly because of factors such as predation or bad weather, which impair old more than young adults. Notably, constant residence is recorded also in single-year studies of three species co-occurring with E. aurinia at the single system site (Fric et al., 2010).

The average values for longevity, which are directly related to residence, were similar to the longevity previously reported for E. aurinia by Wahlberg et al. (2002): 10.7 / 8.9 (days) for males / females. They are also similar or greater than that recorded for other single-brooded Melitaeini [i.e., Melitaea athalia 12.5 / 7.2, M. cinxia 8.2 / 3.3, M. diamina 6.0 / 6.7, Euphydryas maturna 13.3 / 3.3 (all Wahlberg et al., 2002); E. maturna 3.3 / 6.1 (Konvicka et al., 2005a)]. The values exceed longevities of more distantly related species, e.g., B. aquilonaris (Baguette \& Schtickzelle, 2003) and P. eunomia (Schtickzelle et al., 2002). E. aurinia lifespan thus suggests that its adults are quite "hardy", probably because they are protected by chemical defences sequestered from their host plants (cf. Wahlberg, 2001). Although longevity varied among years, some of the individual lifespans reported here, such as 28 days for a male in 2005 (Table 3), may be a record for a single-brooded checkerspot.

Catchability was significantly higher for males both in single system and multiple populations, despite two instances (systems I, VII) in which it was higher for females. A higher male catchability is frequently recorded in butterfly MRR studies (Schtickzelle et al., 2002; Baguette \& Schtickzelle, 2003; Zimmermann et al., 2009; Kadlec et al., 2010), including those on E. aurinia (Schtickzelle et al., 2005; Junker \& Schmitt, 2010; Junker et al., 2010), probably due to their more conspicuous activity, whereas the factorial response of catchability to time is due to variation in weather and marking effort (Schtickzelle et al., 2002; Vlasanek et al., 2009). In any case, if averaged across all years and systems, $16 \%$ of the males and $10 \%$ of the females were captured (mean of $p$ 's in Table 4).

Recruitment was protandrous, as is recorded in many studies of temperate butterflies with discrete generations, including E. aurinia (e.g., Fric et al., 2010; Junker \& Schmitt, 2010). A notable exception with no signs of protandry is that of an alpine population studied by Junker et al. (2010). Protandry results from evolutionary pressure on males to mate with recently emerged females and it is proposed that this may be outweighed by the selection advantage of both sexes emerging synchronously in extreme environments.

\section{Population sizes, sex ratios and densities}

The year-to-year variation in adult numbers recorded in the single system is considerably lower than the published coefficient of variation for identical and related species based on larval nest counts. For Belgian E. aurinia,
Schtickzelle et al. (2005) report a $\mathrm{CV}=0.80$ for a nineyear study, and for E. maturna, Konvicka et al. (2005a) report a $\mathrm{CV}=0.62$. The lower fluctuations in abundance recorded for Czech E. aurinia are likely due to higher baseline values. The nest counts in the two above studies ranged between tens to hundreds, whereas the adult numbers reported here were an order of magnitude higher and the magnitude of the $\mathrm{CV}$ is inversely related to the mean.

The fluctuations in population size were more prominent in females, which were also generally less abundant. Although a higher variation in female numbers appears common in butterflies (e.g., Ehrlich et al., 1984; Schtickezelle et al., 2002; Nowicki et al., 2009), there might be yet another factor causing the increased fluctuations in female numbers in E. aurinia. Appearing a week later than males, the females may be more severely affected by the harvesting of hay, which usually occurs in mid-June, when most of the males have already emerged, whereas some females are still in the pupae and may be destroyed.

The negative density dependence in annual numbers and the observation that both average density values and density ranges were similar in the single system and multiple populations, imply that all of the sites had a similar carrying capacity for E. aurinia. Negative density dependence is recorded for other butterflies (Baguette \& Schticzelle, 2003; Enfjäll \& Leimar, 2005; Nowicki et al., 2009). In E. aurinia, density-dependent limits to population growth may include a shortage of host plant biomass (Succisa pratensis is rarely dominant at the sites and can be depleted by the larvae) and the activity of predators and parasitoids (cf. Konvicka et al., 2005b; Stefanescu et al., 2009). Another density-regulating mechanism might be emigration from overcrowded sites (cf. Brunzel, 2002; Öckinger \& Smith, 2007).

The year to year variation in population density warns against determining the quality of particular sites based on short-term data (Thomas et al., 2002; Hellman et al., 2003). Given that sites display mutually independent population dynamics (Hula et al., 2004; Bulman et al., 2007) the population at a site may be temporarily low rather than the site being of low quality.

\section{Conservation implications}

The estimates for the population of E. aurinia in the Czech Republic range from 25,000 to 32,000 individuals and the existence of a network of sites indicate that this species is not in imminent danger of extinction in this country. The fact that the Superpopulation CLM estimate was lower than the sum of the seven independently modelled systems is attributable to the movement of individuals between sites (migrating butterflies were recorded frequently). Still, the variation in the sizes of the populations among seasons and among sites within a season highlights the necessity to conserve as many local colonies as possible. Further, although most of the colonies are small, conservation should not be restricted to largeareas or high population density sites, as some of the smaller sites may become important if populations decline at the large sites (Hanski, 1999). 
An important novel observation is the phenological asynchronicity of recruitment. Phenological shifts, likely triggered by microclimatic variation among sites (cf. Weiss et al., 1993, for related E. editha), appear to be important for E. aurinia long-term persistence. Whereas a third of the sites are currently managed by conservation groups, using sensitive approaches such as temporary fallows (cf. Schmidt et al., 2008), a third are unmanaged and a third are hay-meadows managed under EU Agricultural schemes (Zimmermann et al., 2010). For practically all of them, untargeted scheme "general mowing" is being applied, requiring whole areas to be cut twice per year. This is detrimental to butterflies (Konvicka et al., 2008; Dover et al., 2010) as it affects an entire landscape synchronously. Given that the Czech sites form a system interconnected by dispersal (manuscript in preparation), asynchronous recruitment ensures that some of the local populations escape the detrimental effects of mowing, which stabilizes the regional metapopulation dynamics.

ACKNOWLEDGEMENTS. Dozens of colleagues and students assisted us in the field during this eight-year study; space limitations prevent us from listing them all here. N. Schtickzelle contributed precious advice on the analysis of the mark-recapture data, T. Schmitt and an anonymous referee helpfully commented on a previous version of the manuscript. The study was supported by the Czech Ministry of Education (LC-6073, MSM 6007665801), the Grant Agency of the Czech Republic (P505/10/2167) and the institutional research plan of the Institute of Entomology (Z50070508).

\section{REFERENCES}

Akgakaya H.R., Burgman M.A. \& Ginzburg L.R. 1999: Applied Population Ecology. Principles and Computer Exercises Using RAMAs Ecolab, 2nd ed. Sinauer Associates, Sunderland, MA, 285 pp.

Anthes N., Fartmann T., Hermann G. \& Kaule G. 2003: Combining larval habitat quality and metapopulation structure the key for successful management of pre-alpine Euphydryas aurinia colonies. J. Insect Conserv. 7: 175-185.

Baguette M. \& Schtickzelle N. 2003: Local population dynamics are important to the conservation of metapopulations in highly fragmented landscapes. J. Appl. Ecol. 40: 404-412.

Baguette M., Vansteenwegen C., Convi I. \& Neve G. 1998 : Sex-biased density-dependent migration in a metapopulation of the butterfly Proclossiana eunomia. Acta Oecol. 19: 17-24.

Betzholtz P.E., Ehrig A., Lindeborg M. \& Dinnétz P. 2007 : Food plant density, patch isolation and vegetation height determine occurrence in a Swedish metapopulation of the marsh fritillary Euphydryas aurinia (Rottemburg, 1775) (Lepidoptera, Nymphalidae) J. Insect Conserv. 11: 343-350.

Boggs C.L. 1987: Within population variation in the demography of Speyeria mormonia (Lepidoptera: Nymphalidae). Ecography 10: 175-184.

BRUNZEL S. 2002: Experimental density-related emigration in the cranberry fritillary Boloria aquilonaris. J. Insect Behav. 15: $739-750$.

Bulman C.R., Wilson R.J., Holt A.R., Bravo L.G., Early R.I., Warren M.S. \& Thomas C.D. 2007: Minimum viable metapopulation size, extinction debt, and the conservation of a declining species. Ecol. Appl. 17: 1460-1473.

BüHLER C. \& SCHMid B. 2001: The influence of management regime and altitude on the population structure of Succisa pratensis: implications for vegetation monitoring. J. Appl. Ecol. 38: 689-698.

Cook L.M., Brower L.P. \& Croze H.J. 1967: The accuracy of a population estimation from multiple recapture data. J. Anim. Ecol. 36: 57-60.

Dover J.W., Rescia A., Fungarino S., Fairburn J., Carey P., Lunt P., Dennis R.L.H. \& Dover C.J. 2010: Can hay harvesting detrimentally affect adult butterfly abundance? $J$. Insect Conserv. 14: 413-418.

EHRLICH P.R. \& HANSKI I. 2004: On the Wings of Checkerspots: a Model System for Population Biology. Oxford Univ. Press, New York, 371 pp.

Ehrlich P.R., White R.R., Singer M.C., McKechnie S.W. \& Gilbert L.E. 1975: Checkerspot butterflies - Historical perspective. Science 188: 221-228.

ENFJÄLL K. \& LeIMAR O. 2005: Density-dependent dispersal in the Glanville fritillary, Melitaea cinxia. Oikos 108: 465-472.

Fleishman E., Ray C., SJogren-Gulve P., Boggs C.L. \& MurPhy D.D. 2002: Assessing the roles of patch quality, area, and isolation in predicting metapopulation dynamics. Conserv. Biol. 16: 706-716.

Fowles A.P. \& SMith R.G. 2006: Mapping the habitat quality of patch networks for the Marsh fritillary Euphydryas aurinia (Rottemburg, 1775) (Lepidoptera, Nymphalidae) in Wales. $J$. Insect Conserv. 10: 161-177.

Fric Z., Hula V., Klimova M., Zimmermann K. \& Konvicka M. 2010: Dispersal of four fritillary butterflies within identical landscape. Ecol. Res. 25: 543-552.

Hanski I. 1999: Metapopulation Ecology. Oxford University Press, Oxford, 266 pp.

Hellmann J.J., Weiss S.B., McLaughlin J.F., Boggs C.L., EhrLich P.R., Launer A.E. \& Murphy D.D. 2003: Do hypotheses from short-term studies hold in the long-term? An empirical test. Ecol. Entomol. 28: 74-84.

Hula V., Konvicka M., Pavlicko A. \& Fric Z. 2004: Marsh fritillary (Euphydryas aurinia) in the Czech Republic: monitoring, metapopulation structure, and conservation of an endangered butterfly. Entomol. Fenn. 15: 231-241.

Junker M. \& SchmitT T. 2009: Demography, dispersal and movement patterns of Euphydryas aurinia (Lepidoptera: Nymphalidae) in the Iberian Peninsula: an alarming example in an increasingly fragmented landscape? J. Insect Conserv. 14: $237-246$.

Junker M., Wagner S., Gros P. \& Schmitt T. 2010: Changing demography and dispersal behaviour: ecological adaptations in an alpine butterfly. Oecologia 164: 891-898.

Konvicka M. \& Benes J. 2008: Monitoring naturových motýlů novinky a problémy $\mathrm{z}$ posledních let [Monitoring of Natura 2000 butterflies - recent news and problems]. Ochrana Prírody 63: 16-20.

Konvicka M., Hula V. \& Fric Z. 2003: Habitat of prehibernating larvae of the endangered butterfly Euphydryas aurinia (Lepidoptera: Nymphalidae): What can be learned from vegetation composition and architecture? Eur. J. Entomol. 100: 313-322.

Konvicka M., CizeK O., Filipova L., Fric Z., Benes J., KrupKa M., ZamecniK J. \& Dockalova Z. 2005a: For whom the bells toll: Demography of the last population of the butterfly Euphydryas maturna in the Czech Republic. Biologia 60: 551-557.

Konvicka M., Hula V. \& Fric Z. 2005b: Picromerus bidens (Heteroptera: Pentatomidae) as predator of the checkerspot Euphydryas aurinia (Lepidoptera: Nymphalidae) Entomol. Fenn. 16: 233-236.

Kuussaari M., Heliola J., Luoto M. \& Poyry J. 2007: Determinants of local species richness of diurnal Lepidoptera in 
boreal agricultural landscapes. Agric. Ecosyst. Environ. 122: 366-376.

Lebreton J., Burnham K.P., Clobert J. \& Anderson D.R. 1992: Modelling survival and testing biological hypotheses using marked animals: a unified approach with case studies. Ecol. Monogr. 62: 67-118.

LiU W.H., WANG Y.F. \& XU R.M. 2006: Habitat utilization by ovipositing females and larvae of the Marsh fritillary (Euphydryas aurinia) in a mosaic of meadows and croplands. $J$. Insect Conserv. 10: 351-360.

Munguira M.L., Martin J., GarciaBarros E. \& Viejo J.L. 1997: Use of space and resources in a Mediterranean population of the butterfly Euphydryas aurinia. Acta Oecol. 18: 597-612.

Nève G., Barascud B., Hughes R., Aubert J., Descimon H., Lebrun P. \& Baguette M. 1996: Dispersal, colonization power and metapopulation structure in the vulnerable butterfly Proclossiana eunomia (Lepidoptera: Nymphalidae). $J$. Appl. Ecol. 33: 14-22.

NiLSSON S.G., Franzen M. \& Jonsson E. 2008: Long-term land-use changes and extinction of specialised butterflies. Insect Conserv. Biodivers. 1: 197-207.

Nowicki P., Bonelli S., Barbero F. \& Balletto E. 2009: Relative importance of density-dependent regulation and environmental stochasticity for butterfly population dynamics. Oecologia 161: 227-239.

ÖCKINGER E. \& SMITH H.G. 2007: Asymmetric dispersal and survival indicate population sources for grassland butterflies in agricultural landscapes. Ecography 30: 288-298.

Oxbrough A.G., Gittings T., O’Halloran J., Giller P.S. \& Kelly T.C. 2006: The initial effects of afforestation on the ground-dwelling spider fauna of Irish peatlands and grasslands. Forest Ecol. Manag. 237: 478-491.

Reidsma P., Tekelenburg T., van den Berg M. \& Alkemade R. 2006: Impacts of land-use change on biodiversity: An assessment of agricultural biodiversity in the European Union. Agric. Ecosyst. Environ. 114: 86-102.

SAARinen K., Jantunen J. \& VAltonen A. 2005: Resumed forest grazing restored a population of Euphydryas aurinia (Lepidoptera: Nymphalidae) in SE Finland. Eur. J. Entomol. 102: 683-690.

Sang A., Teder T., Helm A. \& Partel M. 2010: Indirect evidence for an extinction debt of grassland butterflies half century after habitat loss. Biol. Conserv. 143: 1405-1413.

SAwChiK J., Dufrene M. \& Lebrun P. 2003: Estimation of habitat quality based on plant community, and effects of isolation in a network of butterfly habitat patches. Acta Oecol. 24: $25-33$.

Schmidt M.H., Rocker S., Hanafi J. \& Gigon A. 2008: Rotational fallows as overwintering habitat for grassland arthropods: the case of spiders in fen meadows. Biodivers. Conserv. 17: $3003-3012$.

Schtickzelle N. \& Baguette M. 2004: Metapopulation viability analysis of the bog fritillary butterfly using RAMAS/GIS. Oikos 104: 277-290.

Schtickzelle N., Le Boulenge E. \& Baguette M. 2002: Metapopulation dynamics of the bog fritillary butterfly: demographic processes in a patchy population. Oikos 97: 349-360.

Schtickzelle N., Choutt J., Goffart P., Fichefet V. \& BAguetTe M. 2005: Metapopulation dynamics and conservation of the Marsh fritillary butterfly: Population viability analysis and management options for a critically endangered species in Western Europe. Biol. Conserv. 126: 569-581.

Schtickzelle N., Mennechez G. \& Baguette M. 2006: Dispersal depression with habitat fragmentation in the Bog fritillary butterfly. Ecology 87: 1057-1065.

Singer M.C., Stefanescu C. \& Pen I. 2002: When random sampling does not work: standard design falsely indicates maladaptive host preferences in a butterfly. Ecol. Letters 5: 1-6.

Stefanescu C., Penuelas J., Sardans J. \& Filella I. 2006: Females of the specialist butterfly Euphydryas aurinia (Lepidoptera: Nymphalinae: Melitaeini) select the greenest leaves of Lonicera implexa (Caprifoliaceae) for oviposition. Eur. J. Entomol. 103: 569-574.

Stefanescu C., Planas J. \& Shaw M.R. 2009: The parasitoid complex attacking coexisting Spanish populations of Euphydryas aurinia and Euphydryas desfontainii (Lepidoptera: Nymphalidae, Melitaeini). J. Nat. Hist. 43: 553-568.

Thomas C.D., Wilson R.J. \& Lewis O.T. 2002: Short-term studies underestimate 30-generation changes in a butterfly metapopulation. Proc. R. Soc. Lond. (B, Biol.) 269: 563-569.

Tolman T. \& Lewington R. 1997: Butterflies of Britain and Europe. Harper and Collins, London, $320 \mathrm{pp}$.

Van Dyck H., Van Strien A.J., Maes D. \& Van Swahy C.A.M. 2009: Declines in common, widespread butterflies in a landscape under intense human use. Conserv. Biol. 23: 957-965.

Vlasanek P., Hauck D. \& Konvicka M. 2009: Adult sex ratio in the Parnassius mnemosyne butterfly: Effects of survival, migration, and weather. Israel J. Ecol. Evol. 5: 233-252.

WAHLBERG N. 2001: The phylogenetics and biochemistry of host-plant specialization in Melitaeine butterflies (Lepidoptera: Nymphalidae). Evolution 55: 522-537.

Wahlberg N., Klemetti T., Selonen V. \& Hanski I. 2002: Metapopulation structure and movements in five species of checkerspot butterflies. Oecologia 130: 33-43.

WARREN M.S. 1994: The UK status and suspected metapopulation structure of a threatened European butterly, the Marsh fritillary Eurodryas aurinia. Biol. Conserv. 67: 239-249.

Weiss S.B., Murphy D.D., Ehrlich P.R. \& Metzler C.F. 1993: Adult emergence phenology in checkerspot butterflies: The effects of macroclimate, topoclimate, and population history. Oecologia 96: 261-270.

White G.C. \& Burnham K.P. 1999: Program Mark: survival estimation from populations of marked animals. Bird Study 46: $120-138$.

Zimmermann K., Fric Z., Filipova L. \& Konvicka M. 2005: Adult demography, dispersal and behaviour of Brenthis ino (Lepidoptera: Nymphalidae): How to be a successful wetland butterfly. Eur. J. Entomol. 102: 699-706.

Zimmermann K., Konvicka M., Fric Z. \& Cihakova V. 2009: Demography of a large and common butterfly: Argynnis aglaja (Lepidoptera, Nymphalidae) studied by mark-recapture. Polish J. Ecol. 57: 715-727.

Zimmermann K., Hula V., Fric Z. \& Konvicka M. 2010: Př́iběh evropsky významného druhu hnědáska chrastavcového: Devět let monitoringu a ochrany v západních Čechách. [Story of a butterfly of Community interest, the Marsh fritillary: Nine years of monitoring and conservation in Western Bohemia.] In Brabec J. (ed.): Prrírodní fenomény a zajímavosti západnich Čech. [Natural Phenomenons and Points of Interests of Western Bohemia.] Mezi lesy, Prostibor, pp. 85-99 [in Czech].

Received September 21, 2010; revised and accepetd November 4, 2010 